\title{
PENGARUH BAURAN PROMOSI DAN KUALITAS PELAYANAN TERHADAP KEPUTUSAN PRINCIPAL MENGGUNAKAN PRODUK SURETY BOND DI PT. JAMKRIDA SUMSEL
}

\author{
Ardian Yurdianto ${ }^{*}$, Luis Marnisah², Fakhry Zamzam ${ }^{3}$
}

1, 2, 3 Program Magister Fakultas Ekonomi Universitas IGM Palembang

Article's Information

\section{DOI:}

http://dx.doi.org/10.37253/jgbmr

.$v 2 i 1$

e-ISSN:

2685-3426

EDITORIAL HISTORY:

SUBMISSION: 07 December 2020

ACCEPTED: 30 December 2020

CORRESPONDENCE*:

ardian.vurdianto@gmail.com,

luismarnisah@uigm.ac.id

fakhry@uigm.ac.id

AUTHOR'S ADDRESS:

Palembang, Indonesia

\begin{abstract}
This study entitled The Effect of Promotion Mix and Service Quality on Principal Decisions Using Surety Bond Products at PT Jamkrida Sumsel. This research instrument uses a questionnaire, and using multiple linear regression to process tabulated data from the results of respondents' answers. The results of the study conclude, First, the Promotion Mix Variable (X1) has a positive and significant effect on the Decision of Jamkrida Service Users in South Sumatra (Y; Second, the Service Quality Variable (X2) has a positive and significant effect on the Decision of South Sumatra Jamkrida Service Users (Y); Third, Promotion Mix Variable (X1) is an independent variable whose influence is more dominant on the Decision of Jamkrida Service Users in South Sumatra compared to the variable of service quality; Fourth, the Promotion Mix variable (X1) and Service Quality (X2) have a positive and significant effect on the Decision of Jamkrida Service Users in South Sumatra $(Y)$. This means that the independent variable $(X)$ is increasing together, so the Decision of the Jamkrida Service User of South Sumatra $(Y)$ will increase.
\end{abstract}

Keywords: $\quad$ Promotion Mix, Service Quality, Customer Decisions.

\begin{abstract}
ABSTRAK
Penelitian ini berjudul pengaruh bauran promosi dan kualitas pelayanan terhadap keputusan principal menggunakan produk surety bond di PT. Jamkrida Sumsel. Instrumen penelitian ini menggunakan kuisioner, dan menggunakan regresi linier berganda untuk mengolah data yang telah ditabulasi dari hasil jawaban responden. Hasil penelitian menyimpulkan, Pertama, variabel bauran promosi (X1) berpengaruh secara positif dan signifikan terhadap keputusan pengguna jasa Jamkrida Sumatera Selatan (Y); Kedua, variabel kualitas pelayanan (X2) berpengaruh secara positif dan signifikan terhadap keputusan pengguna jasa Jamkrida Sumatera Selatan (Y); Ketiga, variabel bauran promosi (X1) merupakan variabel independent yang pengaruhnya lebih dominan terhadap keputusan pengguna jasa Jamkrida Sumatera Selatan dibandingkan variabel kualitas pelayanan; Keempat, variabel bauran promosi (X1) dan kualitas pelayanan (X2) berpengaruh positif dan signifikan terhadap keputusan pengguna jasa Jamkrida Sumatera Selatan (Y). Artinya variabel bebas (X) secara bersama-sama semakin meningkat, maka semakin meningkat pula keputusan pengguna jasa Jamkrida Sumatera Selatan (Y).
\end{abstract}

Kata Kunci: Bauran Promosi, Kualitas Pelayanan, Keputusan Pelanggan. 


\section{PENDAHULUAN}

Pemerintah memiliki peranan besar dalam pembangunan suatu Negara, termasuk di dalamnya pembangunan di bidang ekonomi. Fungsi pemerintah dalam bidang ekonomi terkait dengan fungsi stabilisasi, alokasi dan distribusi. Fungsi stabilisasi terkait dengan upaya menciptakan kestabilan ekonomi, sosial politik, hukum, pertahanan dan keamanan. Fungsi alokasi terkait dengan penyediaan barang dan jasa publik dan fungsi distribusi terkait dengan pemerataan pendapatan masyarakat.

Dalam rangka melaksanakan fungsi pemerintah sebagai penyedia barang dan jasa untuk publik, pemerintah melalui departemen-departemen yang ada menjalankan fungsi tersebut dengan melakukan proyek pengadaan barang atau jasa. Ketentuan yang mengatur tentang pengadaan barang atau jasa yang dilaksanakan oleh pemerintah diatur dalam Peraturan Presiden Nomor 54 Tahun 2010 tentang Pengadaan Barang/ Jasa Pemerintah. Tujuannya agar pengadaan barang/jasa pemerintah yang dibiayai dengan Anggaran Pendapatan dan Belanja Negara/Anggaran Pendapatan dan Belanja Daerah (APBN/APBD) dapat dilaksanakan dengan efektif dan efisien dengan prinsip persaingan sehat, transparan, terbuka, dan perlakukan yang adil bagi semua pihak, sehingga hasilnya dapat dipertanggungjawabkan baik dari segi fisik, keuangan maupun manfaatnya bagi kelancaran tugas pemerintah dan pelayanan masyarakat.

Proyek-proyek yang diadakan oleh pemerintah melalui departemendepartemen pada umumnya terbagi menjadi dua, yaitu: proyek konstruksi, yang umumnya berupa pembangunan fasilitas umum seperti pembangunan jalan, rumah sakit dan lainnya dan proyek non konstruksi, berupa pengadaan barang atau jasa guna keperluan operasional departemen terkait ataupun dalam rangka memenuhi visi dan misi pemerintah.

Proyek-proyek tersebut memiliki skala kompleksitas yang cukup besar, seperti perlunya keahlian khusus ataupun modal yang besar dari kontraktor agar bisa melaksanakan proyek tersebut. Hal seperti inilah yang membuat kekhawatiran dari pihak pemerintah selaku pemilik proyek (obligee) terhadap kinerja dari kontraktor (principal) yang mengerjakan proyekproyek tersebut, apakah proyek tersebut dapat berjalan atau tidak.

Salah satu aspek yang penting adalah jaminan yang tersedia untuk pengerjaan proyek tersebut. Dikarenakan menggunakan Anggaran Pendapatan Belanja Negara maka penggunaannya haruslah memperhatikan aspek kepastian dan jaminan agar tepat sasaran sehingga penggunaan Anggaran Pendapatan Belanja Negara bisa dikatakan efektif dan efisien.

Guna mensiasati hal tersebut, didalam Peraturan Presiden No. 54 tahun 2010 diatur adanya keharusan penyerahan suatu jaminan yang diberikan oleh principal kepada obligee. (Presiden RI, 2010). Ada 3 (tiga) macam jaminan yaitu: jaminan yang dikeluarkan oleh bank berupa bank garansi, jaminan yang dikeluarkan oleh perusahaan asuransi (Surety Bond) dan jaminan yang dikeluarkan oleh perusahaan penjaminan (Surety Bond).

Surety Bond adalah perjanjian antara Penjamin (Surety/Penjamin) dengan Terjamin (Principal/Kontraktor/Penyedia) untuk menjamin kepentingan Pemilik Proyek (Oblilgee/Penerima Jaminan), bahwa Terjamin akan memenuhi kewajibannya dalam melaksanakan pekerjaan (proyek) berdasarkan Kontrak (Perjanjian) yang dibuat antara Terjamin/Principal dan Pemilik Proyek/Obligee. Bahwa apabila Terjamin mengalami wanprestasi atau 
gagal memenuhi kewajibannya sebagaimana Kontrak dengan Obligee/Penerima Jaminan, maka Penjamin akan membayarkan kepada Penerima Jaminan/Obligee sebesar kerugian yang dialami oleh Penerima Jaminan/Obligee maksimal sebesar nilai Jaminan. Dan Terjamin/Principal bersedia membayar kembali kepada Penjamin sebesar kerugian yang telah dibayarkan oleh Penjamin kepada Penerima Jaminan/Obligee, berikut bunga, sesuai dengan Perjanjian Mengganti Kerugian (Agreement of Indemnity to Surety) yang telah ditandatangani oleh Terjamin (Principal/Kontraktor). (Surety Bond PT JAMKRIDA SULSEL, n.d.)

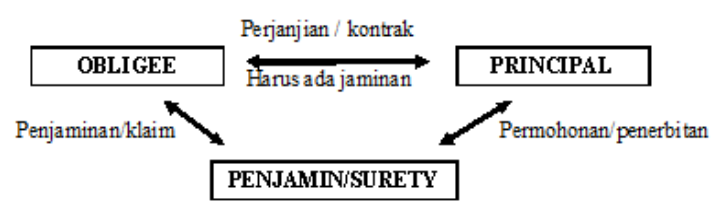

\section{Gambar 1 Mekanisme Penjaminan Surety Bond}

Dari mekanisme penjaminan surety bond diatas, ada hubungan secara langsung antara Penjamin/Perusahaan Penjaminan/Asuransi dengan Principal/Kontraktor. Hubungan ini dimulai dari keinginan Principal untuk menentukan/menunjuk Penjamin yang akan melakukan proses penjaminan untuk proyek yang sedang mereka laksanakan. Atas pengajuan dari Principal tersebut akan diterbitkan Jaminan Surety Bond oleh pihak Penjamin.

Untuk mendapatkan perhatian dari Principal tentunya memerlukan strategi pemasaran yang tepat dan efesien. Hal ini dapat dilihat dari semakin banyaknya Penjamin yang terlibat dalam pemenuhan dan keinginan Principal sehingga menyebabkan setiap Penjamin harus menempatkan orientasi pada Principal sebagai tujuan utama. Penjamin harus dapat memberikan kepada Principal barang atau jasa yang mempunyai nilai lebih tinggi, dengan mutu lebih baik, tarif lebih murah, fasilitas yang memadai dan pelayanan yang lebih baik dari pada pesaingnya.

Dalam dunia perdagangan apabila suatu perusahaan tidak dapat menyusun strategi bisnis dan strategi pemasaran dengan tepat, maka akan mengalami kekalahan dalam bersaing dimana strategi pemasaran merupakan salah satu kegiatan pokok yang dilakukan oleh para pengusaha untuk mempertahankan kelangsungan hidupnya, untuk berkembang dan untuk memperoleh keuntungan.

Promosi merupakan salah satu cakupan bauran pemasaran yang penting dalam memasarkan barang atau jasa yang dihasilkan perusahaan dan juga sebagai suatu cara memberikan informasi kepada masyarakat tentang barang atau jasa yang dihasilkan sebuah perusahaan. (Tjiptono, 2014).

Selain melakukan strategi promosi dalam memasarkan suatu produk, perusahaan juga harus dapat memberikan pelayanan yang bermutu dan berkualitas, seperti memberikan proses yang cepat dan tidak bertele-tele, kualitas pelayanan yang ramah dan baik, dan lain-lain. Pelayanan adalah setiap kegiatan atau manfaat yang ditawarkan suatu pihak pada pihak lain yang tidak berwujud dan tidak mengakibatkan kepemilikan apapun produksi layanan bisa berhubungan dengan produksi fisik maupun tidak (Simamora, 2003:172).

PT. Jamkrida Sumsel sebagai perusahaan penyedia jasa asuransi di Indonesia dengan maksud dan tujuan perusahaan adalah berusaha dalam bidang yang memberikan jasa penjaminan kepada Usaha Mikro, Kecil, Menengah dan Koperasi (UMKMK), yang membutuhkan 
modal usaha namun terkendala masalah jaminan.

Adapun aktivitas penjaminan kredit di PT. Jamkrida Sumsel terdiri dari

1. Pemberian Penjaminan Kredit Mikro, Kecil, dan Kredit Umum;

2. Pemberian Penjaminan Produk Perbankan lainnya;

a. Penjaminan Kredit Serbaguna

b. Penjaminan Kredit Konstruksi dan Pengadaan Barang/ Jasa (KUR)

c. Penjaminan Kredit Usaha Rakyat

d. Kontra Bank Garansi

3. Surety Bond;

4. Pemberian Penjaminan produk dari Lembaga Penyalur Dana Bergulir - Koperasi dan Usaha Mikro, Kecil dan Menengah (LPDB-KUMKM)

Kondisi pendapatan Imbal Jasa Penajminan (IJP) Surety Bond di Jamkrida yang menjadi konsentrasi peneliti, mencapai angka yang cukup baik dan mengalami kenaikan dari tahun ke tahun mulai dari tahun 2017 hingga 2019. Namun kenaikan ini belum diketahui oleh perusahaan berdampak atas aspek bisnis apa. Imbal Jasa Penjaminan (IJP) tahun 2016 adalah sebesar Rp 1.380.616.730,dan pada tahun 2017 terdapat kenaikan IJP yang cukup signifikan yaitu sebesar Rp 3.038.909.149,-, kemudian terjadi penurunan pada tahun 2018 yaitu sebesar 2.318.910.682,- dan pada tahun 2019 yaitu sebesar Rp 2.469.536.500,-. Atas perubahan naik turun nya jumlah penerimaan IJP di atas maka penulis tertarik untuk menganalisa aspek yang menyebabkan perubahan tersebut.

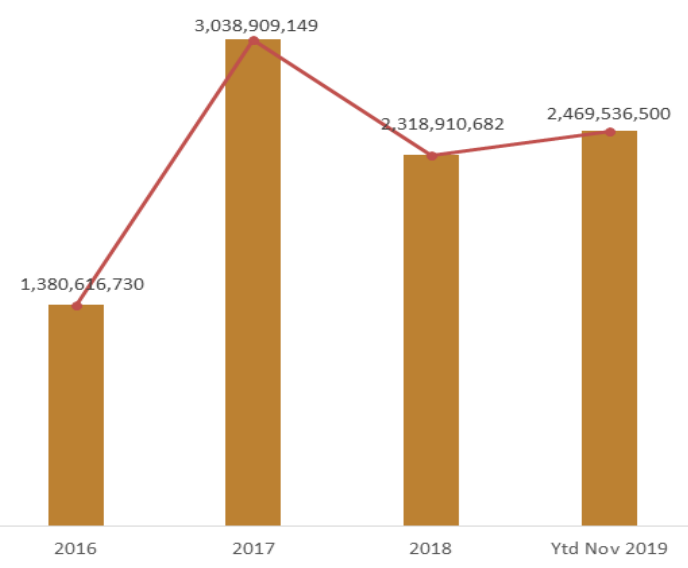

Gambar 2 Imbal Jasa Penjaminan Surety Bond PT Jamkrida Sumsel

Pengguna produk Surety Bond PT. Jamkrida Sumsel adalah para pengusaha yang bergerak dibidang konstruksi/pengadaaan barang atau jasa yang lokasi pengerjaan proyek masih harus berada di wilayah Provinsi Sumatera Selatan. Rata-rata pengguna produk surety bond PT. Jamkrida Sumsel adalah perusahaan yang mendapatkan proyek di pemerintahan seperti Dinas Pekerjaan Umum Provinsi Sumsel, Dinas Perumahan dan Permukiman Provinsi Sumsel dan dinas-dinas kota atau kabupaten yang ada di Provinsi Sumatera Selatan.

Ada dua pihak yang berperan penting dalam penentuan keputusan penggunaan produk surety bond yaitu: Perusahaan/Kontraktor dan Dinas Pemerintahan. Untuk itu perlu dilakukan aspek-aspek pemasaran agar para pengguna produk surety bond PT. Jamkrida Sumsel tertarik untuk memilih PT. Jamkrida Sumsel sebagai penerbit jaminan, sebagai salah satu persyaratan pelaksanaan proyek pengadaan barang atau jasa.

Berdasarkan uraian dari latar belakang di atas, maka peneliti tertarik melkaukan penelitian tesis yang berjudul "Pengaruh Bauran Promosi dan Kualitas Layanan Terhadap Keputusan Principal Untuk 


\section{Menggunakan Produk Surety Bond di PT. Jamkrida Sumsel.”}

\section{Bauran Promosi}

Bauran promosi merupakan alat komunikasi yang terdiri dari kombinasi alat-alat promosi yang digunakan oleh perusahaan. Pada umumnya alat-alat promosi tersebut memiliki hubungan yang erat, sehingga diantaranya tidak dapat dipisahkan karena bersifat saling mendukung dan melengkapi.

Menurut (Kotler \& Armstrong, 2018) mengemukakan bauran promosi adalah gabungan arus informasi secara menyeluruh dan hanya dilakukan oleh satu organisasi atau individu tertentu. Ini berbeda dengan komunikasi pemasaran yang bertujuan untuk memuaskan semua pihak. Semua pihak yang terlibat dalam proses komunikasi pemasaran melakukan cara yang sama yaitu mendengarkan, bereaksi, dan berbicara sampai tercipta hubungan pertukaran yang memuaskan

Alat-alat bauran promosi dikelompokkan menjadi 4 bagian yaitu :

\section{Periklanan}

Iklan adalah bentuk komunikasi yang dibayar yang bersifat nonpersonal untuk menginformasikan, membujuk dan mengingatkan konsumen dalam memengaruhi pengambilan keputusan.

\section{Promosi Penjualan}

Menurut Assauri (2011:282), promosi penjualan adalah usaha penjualan khusus (special selling efforts) untuk mendorong pembelian suatu produk oleh konsumen dengan cara yang bervariasi, seperti pameran dagang, insentif penjualan, kupon dan sebagainya.

\section{Publisitas}

Publisitas merupakan salah satu bagian tugas hubungan masyarakat. Setiap perusahaan akan berusaha menciptakan hubungan masyarakat yang baik agar mendapatkan publisitas yang baik pula.
Alat-alat utama dalam hubungan masyarakat bisa melalui terbitan berupa brosur, artikel, berita berkala dan menyelenggarakan acara-acara khusus seperti seminar, pameran serta pemberian dana sponsor.

\section{Penjualan Personal}

Penjualan personal dibutuhkan untuk meyakinkan konsumen terhadap kualitas produk yang ditawarkan dibanding produk pesaingnya. Penjualan personal sangat efektif dalam usaha menciptakan kepercayaan yang tinggi terhadap produk yang ditawarkan dan mengenalkan jenis produk yang belum dikenal oleh konsumen melalui peragaan agar konsumen lebih mudah mengenalnya. Penjualan personal juga biasa digunakan dalam memasarkan produk yang bernilai tinggi dan produkproduk yang memerlukan pengamanan seperti kamera dan telepon seluler.

\section{Kualitas Layanan}

Dalam perspektif TQM (Total Quality Management) kualitas dipandang secara luas, yaitu tidak hanya aspek hasil yang ditekankan, tetapi juga meliputi proses, lingkungan dan manusia. Hal ini jelas tampak dalam defenisi yang dirumuskan oleh Kotler (2009:49) kualitas adalah "seluruh ciri serta sifat suatu produk atau pelayanan yang berpengaruh pada kemampuan untuk memuaskan kebutuhan yang dinyatakan atau yang tersirat". Ini jelas merupakan definisi kualitas yang berpusat pada konsumen, seorang produsen dapat memberikan kualitas bila produk atau pelayanan yang diberikan dapat memenuhi atau melebihi harapan konsumen. Jadi dapat disimpulkan bahwa kualitas adalah suatu keseluruhan ciri dan karekteristik yang dimiliki suatu produk/jasa yang dapat memberikan kepuasan konsumen.

Walaupun kualitas jasa lebih sulit didefinisikan dan dinilai dari pada kualitas produk, pelanggan tetap akan memberikan 
penilaian terhadap kualitas jasa, dan Jamkrida Sumsel perlu memahami bagaimana sebenarnya pengharapan kontraktor sehingga Jamkrida Sumsel dapat merancang jasa yang ditawarkan secara efektif.

Menurut Kotler (2009:25) kualitas pelayanan merupakan totalitas dari bentuk karakteristik barang dan jasa yang menunjukkan kemampuannya untuk memuaskan kebutuhan pelanggan, baik yang nampak jelas maupun yang tersembunyi. Bagi perusahaan yang bergerak di sektor jasa, pemberian pelayanan yang berkualitas pada pelanggan merupakan hal mutlak yang harus dilakukan apabila perusahaan ingin mencapai keberhasilan. Dengan kata lain, faktor utama yang mempengaruhi kualitas pelayanan adalah pelayanan yang diharapkan pelanggan/pengunjung dan persepsi masyarakat terhadap pelayanan tersebut. Nilai kualitas pelayanan tergantung pada kemampuan perusahaan dan stafnya dalam memenuhi harapan pelanggan secara konsisten

\section{Keputusan Konsumen}

Menurut Kotler dan Armstrong (2012:157), perilaku keputusan pembelian mengacu pada perilaku pembelian akhir dari konsumen, baik individual, maupun rumah tangga yang membeli barang dan jasa untuk konsumsi pribadi. Selanjutnya Kotler dan Keller (2009:240) menyatakan bahwa, "Keputusan pembelian adalah konsumen membentuk niat untuk membeli merek yang paling disukai." Berdasarkan definisi-definisi tersebut, maka dapat disimpulkan bahwa keputusan pembelian adalah perilaku konsumen membeli suatu barang atau jasa yang mereka sukai.

Para konsumen akan melewati lima tahapan dalam proses pengambilan keputusan. Kelima tahapan itu adalah pengenalan masalah kebutuhan, pencarian informasi, evaluasi alternatif, keputusan pembelian, dan perilaku pasca pembelian. Proses keputusan pembelian bisa dilihat pada gambar di bawah ini:

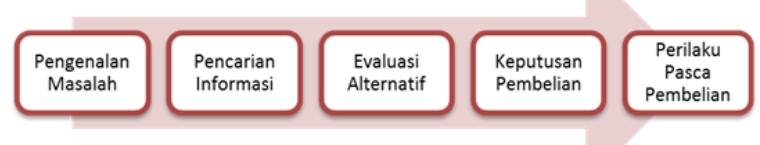

Sumber : Kotler (2009:184)

\section{Gambar 3}

\section{Tahapan Pengambilan Keputusan}

Rumusan masalah dalam penelitian ini adalah: 1) Bagaimanakah pengaruh bauran promosi terhadap keputusan principal untuk menggunakan surety bond PT. Jamkrida Sumsel?; 2) Bagaimanakah pengaruh kualitas pelayanan terhadap keputusan principal untuk menggunakan surety bond PT. Jamkrida Sumsel?; 3) Faktor manakah yang lebih dominan antara bauran promosi dan kualitas pelayanan terhadap keputusan Principal untuk menggunakan Surety Bond PT. Jamkrida Sumsel?

Dari penelitian yang dilakukan oleh Jackson RS Weenas (2013), mengenai kualitas produk, harga, promosi dan kualitas pelayanan berpengaruh signifikan terhadap keputusan pembelian. Begitu pula dengan penelitian yang dilakukan oleh Muhammad Ulil Absor, Leonardo B Hasiolan, Djamaludin Malik tentang pengaruh harga, promosi, dan kualitas produk terhadap keputusan pembelian produk torabika duo (studi kasus di area kabupaten Demak), menyatakan bahwa harga, promosi dan produk berpengaruh terhadap keputusan pembelian baik secara simultan maupun parsial.

Kurnia Dewi, SE,MM dalam penelitiannya mengenai pengaruh promosi dan kualitas pelayanan terhadap keputusan pembelian pada duta ponsel rengat kabupaten Indragiri Hulu, mengemukakan bahwa Variabel Promosi dan Kualitas Pelayanan secara parsial dan simultan berpengaruh positif dan 
signifikan terhadap Keputusan Pembelian pada Duta Ponsel Rengat Kabupaten Indragiri Hulu. Sama halnya dengan penelitian dari Herry Widagdo (2018), mengemukakan bahwa variabel kualitas layanan dan variabel promosi berpengaruh secara simultan terhadap keputusan konsumen membeli komputer. Pengaruh variabel kualitas layanan lebih dominan dibandingkan variabel promosi.

\section{Kerangka Pemikiran}

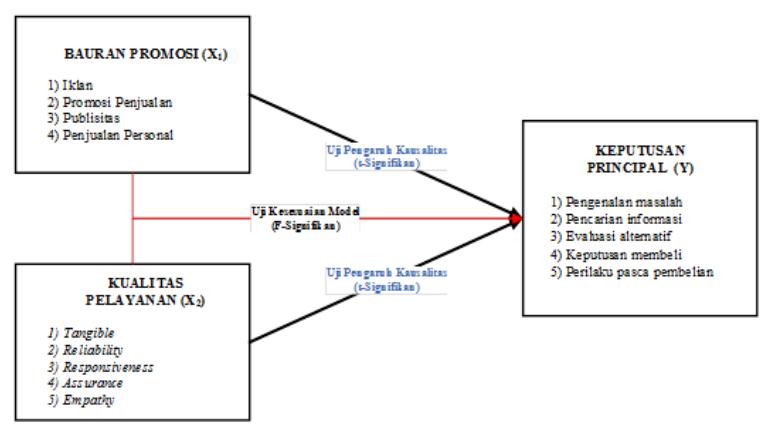

\section{Gambar 4 \\ Kerangka Pemikiran Penelitian}

\section{METODE PENELITIAN}

Penelitian ini dirancang sebagai suatu penelitian yang bersifat eskplorasi deskriptif dan eksplorasi kausal. Eksplorasi deskriptif dimaksudkan untuk mendefinisikan nilai-nilai variabel yang diteliti, sedangkan eksplorasi kausal (Sugiyono, 2008, 37) bertujuan untuk mengetahui hubungan sebab akibat dimana variabel independen: bauran promosi $\left(\mathrm{X}_{1}\right)$ dan kualitas layanan $\left(\mathrm{X}_{2}\right)$ mempengaruhi variabel dependen: keputusan principal (Y)

Hipotesis yang akan diuji dalam penelitian ini bahwa diduga bauran promosi secara parsial berpengaruh signifikan terhadap keputusan Principal untuk menggunakan surety bond PT. Jamkrida Sumsel, diduga kualitas layanan secara parsial berpengaruh signifikan terhadap keputusan Principal untuk menggunakan surety bond PT. Jamkrida Sumsel, diduga bauran promosi dan kualitas layanan secara simultan berpengaruh signifikan terhadap keputusan Principal untuk menggunakan surety bond PT. Jamkrida Sumsel.

Metode yang digunakan dalam pengambilan sampel adalah purposive random sampling, yaitu salah satu teknik sampling dengan menggunakan pertimbangan dimana peneliti menentukan pengambilan sampel dengan cara menetapkan ciri-ciri khusus yang sesuai dengan tujuan penelitian sehingga diharapkan dapat menjawab permasalahan penelitian.

\section{Teknik Pengumpulan Data}

Teknik pengumpulan data yang digunakan dalam penelitian ini adalah metode kuesioner yaitu teknik pengumpulan data yang dilakukan dengan cara memberi kuesioner atau seperangkat pertanyaan atau pernyataan tertulis kepada responden (Sugiyono, 2016).

\section{HASIL DAN PEMBAHASAN \\ Gambaran Umum Objek Penelitian}

Berdirinya Perseroan Terbatas Penjaminan Kredit Daerah Sumatera Selatan (PT. Jamkrida Sumsel) dalam rangka menjembatani kepentingan Usaha Mikro Kecil Menengah dan Koperasi (UMKMK) untuk mendapatkan akses kredit atau pembiayaan melalui bank atau kreditur lainnya dan memberikan jasa penjaminan kepada UMKMK yang membutuhkan modal usaha namun terkendala masalah jaminan, khususnya dalam mewujudkan kesejahteraan masyarakat Sumsel, berdasarkan Peraturan Daerah Provinsi Sumatera Selatan Nomor 9 Tahun 2012 tanggal 12 Juni 2012 tentang Pembentukan Perseroan 
Terbatas Penjaminan Kredit Daerah Sumatera Selatan.

Penelitian ini di lakukan untuk melihat efektifitas pengaruh strategi bauran Pemasaran dan kualitas pelayanan Jamkrida Sumsel terhadap keputusan pelanggan pengguna jasa jaminan kredit daerah (Jamkrida Sumsel). Dimana hasil penelitian ini nantinya akan digunakan sebagai landasan dasar dalam mengambil kebijakan di masa yang akan datang oleh pihak manajemen perusahaan.

Objek penelitian terdiri dari 80 perusahaan (Client Jamkrida Sumsel) yang pernah menggunakan jasa Jamkrida Sumsel. Adapun pengelompokan karakteristik responden disusun berdasarkan kategori sebagai berikut:

\section{Karakteristik Profil Responden}

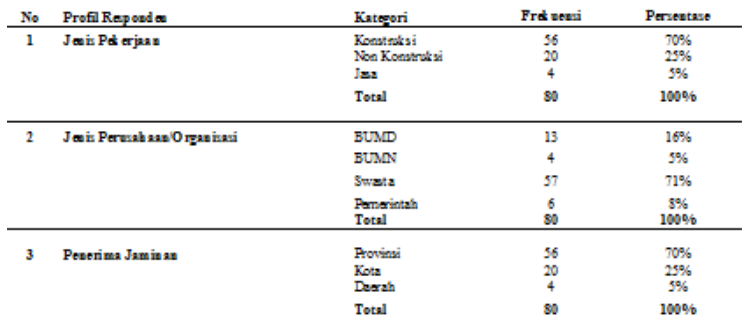

Berdasarkan tabel 4.1. di atas, dapat dilihat pengelompokan karakteristik profil responden. Kategori pertama, yaitu jenis pekerjaan: terdapat 56 jenis perusahaan konstruksi (70\%), 20 jenis perusahaan non konstruksi (25\%), dan 4 jenis perusahaan yang bergerak dibidang jasa (5\%). Hal ini dapat disimpulkan bahwa mayoritas principal Jamkrida Sumsel adalah perusahaan yang bergerak di bidang konstruksi (pembangunan fisik). Kategori kedua, yaitu jenis perusahaan/organisasi: terdapat 13 perusahaan BUMD (16\%), 4 perusahaan BUMN (5\%), 57 perusahaan swasta $(71 \%)$, dan institusi pemerintah sebanyak 6 institusi (8\%). Dari rekapitulasi data ini dapat disimpulkan bahwa mayoritas principal Jamkrida Sumsel adalah perusahaan swasta di wilayah Sumatera Selatan. Dan kategori ketiga, yaitu penerima jaminan: terdapat
56 responden $(70 \%)$ berasal dari Provinsi, 20 responden $(25 \%)$ Kota, dan terakhir 4 Responden (5\%) berasal dari dalam daerah. Jadi berdasarkan data ini dapat disimpulkan bahwa mayoritas principal Jamkrida Sumsel Berasal dari Provinsi.

\section{Uji Instrument Penelitian}

Pada penelitian dibidang sosial seperti manajemen, psikologi dan sosiologi umumnya variabel - variabel penelitiannya dirumuskan sebagai sebuah variabel latent atau un - observed (sering juga disebut konstruk) yaitu variabel yang tidak dapat diukur secara langsung, tetapi dibentuk melalui dimensi atau indikator indikator yang diamati. Biasanya indikator - indikator ini diamati dengan menggunakan kuesioner atau angket yang bertujuan untuk mengetahui pendapat responden tentang suatu hal. Oleh sebab itu untuk membuat suatu kuesioner dikatakan memenuhi syarat atau tidak maka dilakukanlah pengujian instrument penelitian. (Ghozali, 2016:47).

\section{Uji Validitas Data}

Instrumen yang valid merupakan syarat mutlak untuk mendapatkan hasil penelitian yang valid Pengujian validitas instrumen dalam penelitian ini dilakukan dengan membandingkan nilai r-hitung (Corrected Item-Total Correlation) pada setiap butir pertanyaan dengan nilai $\mathrm{r}$ tabel (Product Moment Pearson). Jika nilai r-hitung lebih besar dari $\mathrm{r}$ - tabel ( $\mathrm{r}$ hitung $>\mathrm{r}-$ tabel), maka butir pertanyaan dinyatakan valid (Ghozali, 2016:79). Nilai r-tabel untuk 80 responden adalah sebesar : 0.1829 .

Berikut ini ditampilkan hasil uji validitas kuisioner pada masing - masing variabel: 
Tabel Uji Validitas Variabel Bauran Promosi

\begin{tabular}{|c|c|c|c|c|c|}
\hline \multicolumn{6}{|c|}{ Ism-Tonl Stristics } \\
\hline & $\begin{array}{l}\text { Scale Mean if } \\
\text { Itrm Delted }\end{array}$ & $\begin{array}{c}\text { Scale } \\
\text { Variance if } \\
\text { Itom Deleted }\end{array}$ & $\begin{array}{l}\text { Corrected Item- } \\
\text { Tatal Comelation }\end{array}$ & $\begin{array}{l}\text { Squared.Mrifiple } \\
\text { Comelation }\end{array}$ & $\begin{array}{c}\text { Crombach's } \\
\text { Alpha iflem } \\
\text { Deleted }\end{array}$ \\
\hline PRKL 1 & 332522 & 44,365 & 517 & .42 & .880 \\
\hline DRKL 2 & 317124 & 42581 & .600 & .645 & .875 \\
\hline PRKL 3 & 317124 & 42.046 & .671 & .682 & .871 \\
\hline PP1 1 & 324032 & 42236 & .664 & 514 & .872 \\
\hline pp.2 & 323514 & 42.961 & .618 & 567 & .875 \\
\hline$p p .3$ & 326505 & 41.285 & .747 & .688 & .867 \\
\hline Publ 1 & 321681 & 43.701 & 593 & .437 & .876 \\
\hline Pub2 2 & 321029 & 41.593 & .683 & 589 & .870 \\
\hline Pub3 & 318700 & 42.149 & .674 & 533 & .871 \\
\hline PS.1 & 314612 & 4.415 & .463 & .488 & .883 \\
\hline PS.2 & 323517 & 44906 & .457 & 501 & .883 \\
\hline PS. 3 & 314613 & 46.019 & 347 & 312 & .889 \\
\hline
\end{tabular}

Tabel Uji Validitas Variabel Kualitas Pelayanan

\begin{tabular}{|c|c|c|c|c|c|}
\hline \multicolumn{6}{|c|}{ Item-Toml Sméstics } \\
\hline & $\begin{array}{l}\text { Scale Mean if } \\
\text { Itrm Deleted }\end{array}$ & $\begin{array}{l}\text { Scale Variance } \\
\text { if Itsm Delesed }\end{array}$ & $\begin{array}{l}\text { Corrected Item- } \\
\text { Total Corelation }\end{array}$ & $\begin{array}{l}\text { Squared Mnutiple } \\
\text { Correlation }\end{array}$ & $\begin{array}{l}\text { Cron boch's } \\
\text { Alphin if Item } \\
\text { Deleted }\end{array}$ \\
\hline To 1 & 426236 & 53.959 & 504 & .624 & .838 \\
\hline Tक् 2 & 422155 & 52526 & .638 & .657 & .830 \\
\hline Tog 3 & 426239 & 56.316 & 331 & .483 & .847 \\
\hline Emp. 1 & 424665 & 56.674 & .298 & .361 & .849 \\
\hline $\operatorname{Emp} 2$ & 422152 & 53.583 & 544 & .502 & .835 \\
\hline Emp 3 & 429866 & 56.432 & 303 & .216 & .849 \\
\hline Rib. 1 & 432050 & 53.764 & .496 & 565 & .838 \\
\hline $\mathrm{Rtb} 2$ & 43.1056 & 54.785 & .421 & .491 & .842 \\
\hline $\mathrm{Rtb}_{3}$ & 430491 & 54.630 & .431 & .456 & .842 \\
\hline Ræ. 1 & 43.0490 & 54.526 & .445 & .461 & .841 \\
\hline$R s p 2$ & 43.0494 & 52079 & .639 & .708 & .830 \\
\hline Rspo 3 & 428366 & 53.115 & .599 & .529 & .832 \\
\hline Ass 1 & 427416 & 54.045 & 512 & .566 & .837 \\
\hline Ass 2 & 426241 & 54.450 & .499 & .528 & .838 \\
\hline Ass 3 & 424661 & 53.826 & .537 & .421 & .836 \\
\hline
\end{tabular}

Tabel Uji Validitas Variabel Keputusan Principal

\begin{tabular}{|l|c|c|c|c|c|}
\hline \multicolumn{7}{|c|}{ Item-Total Statistics } \\
\hline & $\begin{array}{c}\text { Scale Mean if Item } \\
\text { Deleted }\end{array}$ & $\begin{array}{c}\text { Scale } \\
\text { Variance if } \\
\text { Item } \\
\text { Deleted }\end{array}$ & $\begin{array}{c}\text { Corrected } \\
\text { Item-Total } \\
\text { Correlation }\end{array}$ & $\begin{array}{c}\text { Squared } \\
\text { Multiple } \\
\text { Correlation }\end{array}$ & $\begin{array}{c}\text { Cronbach's } \\
\text { Alpha if } \\
\text { Item } \\
\text { Deleted }\end{array}$ \\
\hline KP.1 & 29.918 & 35.209 & 0.355 & 0.31 & 0.867 \\
\hline KP.2 & 28.2999 & 33.469 & 0.457 & 0.557 & 0.861 \\
\hline KP.3 & 28.2995 & 32.439 & 0.596 & 0.547 & 0.85 \\
\hline KP.4 & 29.0388 & 32.335 & 0.604 & 0.443 & 0.85 \\
\hline KP.5 & 28.9906 & 32.966 & 0.567 & 0.449 & 0.853 \\
\hline KP.6 & 29.2715 & 32.002 & 0.64 & 0.548 & 0.847 \\
\hline KP.7 & 28.7505 & 33.424 & 0.54 & 0.344 & 0.855 \\
\hline KP.8 & 28.7502 & 31.27 & 0.679 & 0.625 & 0.844 \\
\hline KP.9 & 28.4569 & 32.247 & 0.622 & 0.478 & 0.849 \\
\hline KP.10 & 28.2997 & 32.189 & 0.622 & 0.525 & 0.848 \\
\hline KP.11 & 28.2995 & 33.815 & 0.476 & 0.4 & 0.859 \\
\hline & & & & & \\
\hline
\end{tabular}

Berdasarkan hasil olah data SPSS pada butir pernyataan responden di atas. Maka dapat dilihat bahwa secara keseluruhan nilai (r-hitung > r-tabel) / Lihat tabel (CITC > 0.1829). Hal ini dapat disimpulkan bahwa seluruh butir pernyataan yang diajukan pada instrument penelitian ini dinyatakan telah memenuhi syarat asumsi yang berlaku (Valid) dan dapat dilanjutkan ke tahap pengujian berikutnya.

\section{Uji Reliabilitas Data}

Reliabilitas menunjukkan konsistensi dan stabilitas dari suatu skor (skala pengukuran). Reliabilitas artinya adalah tingkat keterpercayaan hasil suatu pengukuran. Uji realibilitas adalah indeks yang menunjukkan sejauh mana suatu alat pengukur dapat dipercaya atau diandalkan bila digunakan berkali - kali berpotensi akan menghasilkan data yang sama (reliabel).

Hasil uji reliabilitas data pada masing masing variabel penelitian dapat dilihat pada tabel berikut:

Tabel Hasil Uji Reliabilitas Data

\begin{tabular}{|c|c|c|c|}
\hline \multicolumn{4}{|c|}{ Reliability Statistics } \\
\hline Variabel Penelitian & $\begin{array}{c}\text { Cronbach's } \\
\text { Alpha }\end{array}$ & $\begin{array}{c}\text { Cronbach's Alpha } \\
\text { Based on } \\
\text { Standardized } \\
\text { Items } \\
\end{array}$ & $N$ of Items \\
\hline Bauran Promosi (X1) & 0.885 & 0.885 & 12 \\
\hline Kualitas Pelayanan (X2) & 0.848 & 0.849 & 15 \\
\hline Keputusan Pengguna Jasa ( $(\mathrm{)})$ & 0.865 & 0.864 & 11 \\
\hline
\end{tabular}

Pengujian reliabilitas instrumen penelitian dilakukan dengan metode analisis Cronbach's Alpha. Adapun kriteria pengujiannya adalah, jika nilai Cronbach's Alpha lebih besar dari 0,60 (Cronbach's Alpha > 0,60), maka instrumen penelitian dinyatakan reliabel (Ghozali, 2016). Berdasarkan hasil pengolahan data output SPSS yang ditampilkan pada tabel diatas, maka dapat disimpulkan bahwa semua variabel yang dimasukkan ke dalam model penelitian ini dinyatakan telah reliabel dan dapat di lanjutkan ke pengujian berikutnya. 


\section{Uji Asumsi Klasik Uji Multikolinieritas}

Uji multikolinearitas digunakan untuk mengetahui ada atau tidaknya korelasi antar variabel bebas (X). Hal tersebut penting karena salah satu syarat sebuah model regresi yang baik adalah tidak terjadi multikolinearitas. Apabila nilai VIF lebih kecil dari pada 10 dan nilai tolerance value tidak ada yang kurang dari $(<0,10)$ maka dapat disimpulkan tidak terjadi multikolinearitas.

Tabel Hasil Uji Multikolinieritas

\begin{tabular}{|c|c|}
\hline \multicolumn{2}{|c|}{ Coefficients $^{\mathrm{a}}$} \\
\hline Collinearity Statistic & \\
\hline Tolerance & VIF \\
\hline 0.715 & 1.399 \\
\hline 0.715 & 1.399 \\
\hline
\end{tabular}

Berdasarkan data hasil uji multikolinearitas di dapatlah hasil perhitugan yang mengindikasikan bahwa tidak terdapat multikolinearitas yang serius. Hasil ini terlihat dari hasil perhitungan nilai Variance Inflation Factor (VIF) yang menunjukkan tidak ada satupun variable independen yang memiliki nilai VIF lebih dari 10 . Selanjutnya nilai Tolerance juga menunjukkan hal yang sama, tidak ada variable yang memiliki nilai tolerance kurang dari $(<0.10)$. Jadi dapat disimpulkan bahwa tidak ada multikolonieritas yang serius antar variable independen dalam model regresi pada penelitian ini

\section{Uji Heteroskedastisitas}

Pengujian heterokedasitas bertujuan untuk mengetahui apakah dalam model regresi terdapat ketidaksamaan varians dari residual satu ke pengamatan yang lainnya. Berdasarkan hasil uji heterokesdasitas dengan menggunakan SPSS maka didapatkanlah hasil sebagai berikut:

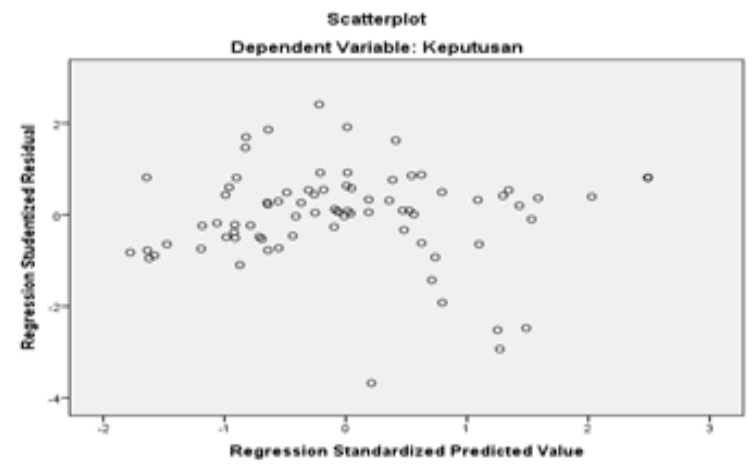

Gambar 5 Grafik Scatterplot

Dari hasil pengujian, tidak terdapat data yang membentuk pola tertentu, seperti titik-titik yang membentuk pola tertentu dan teratur yaitu bergelombang atau melebar kemudian menyempit, dan dari grafik Plot tidak ada pola yang jelas serta titik-titik menyebar diatas dan dibawah angka 0 pada sumbu $\mathrm{Y}$ maka dapat disimpulkan bahwa tidak terjadi heterokedasitas.

\section{Uji Normalitas Data}

Uji normalitas bertujuan untuk mengetahui apakah masing-masing variabel berdistribusi normal atau tidak. Uji normalitas diperlukan karena untuk melakukan pengujian-pengujian variabel lainnya dengan mengasumsikan bahwa nilai residual mengikuti distribusi normal.

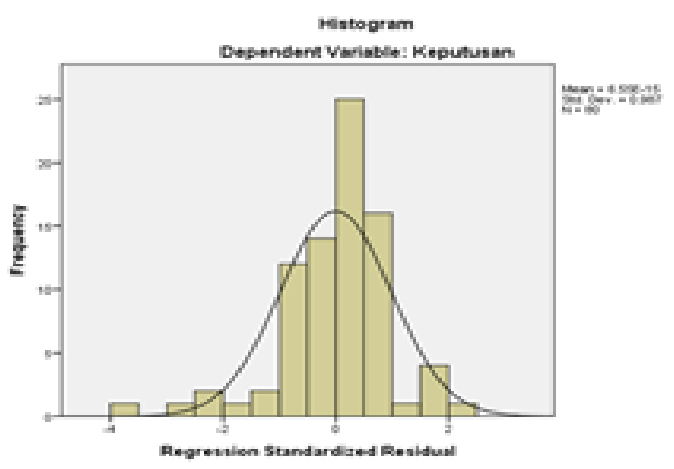

Gambar 6 Grafik Histogram 
Berdasarkan hasil olah data dengan SPSS, terlihat pada grafik histogram data berada di dalam garis diagonal, dapat disimpulkan bahwa data pada penelitian ini terdistribusi dengan normal.

\section{Analisis Deskriptif Variabel Penelitian Analisis Deskriptif Bauran Promosi Jamkrida Sumsel}

Berikut ini di tampilkan rekapitulasi pernyataan responden mengenai variabel bauran promosi Jamkrida Sumsel yang terdiri dari 4 dimensi utama, yaitu periklanan, promosi penjualan, publisitas, dan penjualan personal. Hasil analisis deskriptif menunjukkan sejauh mana penerapan bauran promosi di lingkungan Jamkrida Sumsel.

Tabel Rekapitulasi Analisis Deskriptif Bauran Promosi

\begin{tabular}{rlc} 
No & Dimensi & Score \\
\hline 1 & Periklanan & 3.20 \\
2 & Promosi Penjualan & 3.13 \\
3 & Publisitas & 2.88 \\
4 & Penjualan Personal & 3.43 \\
\hline & Rata - Rata & 3.16 \\
\hline
\end{tabular}

Dari tabel di atas, dapat dilihat pada dimensi pertama yaitu periklanan, ratarata skor menunjukkan angka 3,20 yang masuk pada kategori sedang. Hal ini dapat disimpulkan bahwa periklanan yang selama ini dilakukan belum maksimal dan perlu untuk ditingkatkan di masa yang akan datang. Begitu pula pada dimensi kedua mengenai "promosi penjualan", secara rata-rata angka skor pada dimensi promosi penjualan mendapatkan nilai 3.13, yang masuk pada kategori skor sedang. Sama halnya pada dimensi yang ketiga mengenai "Publisitas", skor rata rata dimensi publisitas mendapat nilai skor sebesar 2.88 atau pada kategori skor sedang. Hal ini dapat disimpulkan bahwa saat ini promosi penjualan dan publisitas yang dilakukan Jamkrida Sumsel belum begitu maksimal dan harus ditingkatkan lagi pada masa dating. Kegiatan publisitas sendiri masih sangat jarang di lakukan oleh Jamkrida Sumsel.

Pada dimensi keempat mengenai "personal selling". Skor rata-rata yang didapat adalah sebesar 3.43 atau pada kategori skor tinggi. Hal ini dapat disimpulkan bahwa kegiatan personal selling merupakan kegiatan yang memiliki power yang kuat untuk mempengaruhi pelanggan dalam hal ini pengguna jasa Jamkrida Sumsel.

\section{Analisis Deskriptif Kualitas Pelayanan Jamkrida Sumsel}

Berikut ini di tampilkan rekapitulasi pernyataan responden mengenai variabel Kualitas Pelayanan Jamkrida Sumsel yang terdiri dari 5 dimensi utama. Yaitu Tangibles (Bukti Fisik), Empathy (Empati), Reliability (Kehandalan), Responsiveness (Daya Tanggap), dan Assurance (Jaminan). Hasil analisis deskriptif menunjukkan sejauh mana kualitas pelayanan yang selama ini diberikan Jamkrida Sumsel.

\section{Tabel Rekapitulasi Analisis Deskriptif Kualitas Pelayanan}

\begin{tabular}{clc} 
No & Dimensi Kualitas Pelayanan & Score \\
\hline 1 & Tangibles (Bukti Fisik) & 2.84 \\
2 & Empathy (Empati) & 2.95 \\
3 & Reliability (Kehandalan) & 3.00 \\
4 & Responsiveness (Daya Tang gap) & 2.85 \\
5 & Assurance (Jaminan) & 3.01 \\
& Rata - Rata & 2.93
\end{tabular}

Dari data di atas, dimensi tangibles (bukti fisik), secara keseluruhan mendapatkan skor 2.84, yakni kategori skor sedang. Hal ini dapat disimpulkan bahwa kualitas pelayanan dari sisi bukti fisik belum begitu baik dan wajib harus di tingkatkan di masa yang akan datang. Pada dimensi emphaty (empati), secara keseluruhan mendapat skor 2,95 atau pada kategori skor sedang. Begitu juga dengan dimensi reliability (kehandalan), secara keseluruhan skor pada dimensi reliability adalah 3,00, kategori skor sedang. 
Hal ini dapat disimpulkan bahwa kualitas pelayanan dari sisi empati dan reliability masih belum begitu baik, dibutuhkan perbaikan serta kesadaran secara individu bagi karyawan yang bertugas untuk lebih meningkatkan rasa empati dan kepedulian agar pelanggan yang datang dapat merasa puas dengan pelayanan yang disajikan Jamkrida Sumsel, dan tingkat kehandalan pelayanan belum begitu baik dan membutuhkan perbaikan di masa yang akan datang.

Pada dimensi responsiveness (daya tanggap), secara keseluruhan dimensi responsiveness mendapat nilai rata-rata 2,85, yaitu kategori sedang. Dapat disimpulkan bahwa daya tanggap petugas Jamkrida Sumsel saat ini belum sesuai dengan standar yang diharapkan, sehingga dibutuhkan perbaikan serta kesadaran bagi karyawan untuk meningkatkan kinerjanya di masa yang akan datang pada setiap lini. Sama halnya dengan diimensi Assurance (Jaminan), skor rata-rata untuk dimensi Assurance (Jaminan) adalah 3,01, masuk pada kategori skor sedang. Dapat disimpulkan bahwa kualitas pelayanan dari sisi jaminan (Assurance) belum begitu memuaskan sehingga perlu untuk di tingkatkan di masa yang akan datang.

\section{Analisis Deskriptif Keputusan Pengguna Jasa Jamkrida Sumsel}

Berikut ini di tampilkan rekapitulasi pernyataan responden mengenai variabel keputusan pengguna jasa Jamkrida Sumsel yang terdiri dari 5 dimensi utama, yaitu: Evaluasi Masalah, Pencarian Informasi, Evaluasi Alternatif, Keputusan Pembelian, Pelayanan Pasca Pembelian. Hasil analisis deskriptif menunjukkan karakteristik terbentuknya faktor - faktor dominan yang membentuk keputusan pengguna jasa Jamkrida Sumsel sebagai berikut :
Tabel Rekapitulasi Analisis Deskriptif Keputusan Pengguna Jasa

\begin{tabular}{clc} 
No & Dimensi & Score \\
\hline 1 & Evaluasi Masalah & 3.45 \\
2 & Pencarian Informasi & 3.00 \\
3 & Evaluasi Alternatif & 3.00 \\
4 & Keputusan Pembelian & 2.85 \\
5 & Pelayanan Pasca Pembelian & 2.96 \\
& Rata - Rata & 3.05
\end{tabular}

Dimensi pertama yaitu "Evaluasi Masalah" secara umum mendapatkan skor 3,45 kategori nilai tinggi. Dapat disimpulkan bahwa pelanggan jamkrida sumsel memilih Jamkrida atas dasar kebutuhan yang mutlak mengenai jasa jaminan kredit yang kredibel dan sesuai dengan legalitas pekerjaan yang ada di wilayah Sumatera Selatan. Pada dimensi "Pencarian Informasi". Skor rata-rata yang didapatkan adalah 3.00. Dapat disimpulkan bahwa dominan pelanggan jamkrida mendapatkan informasi melalui teman - teman / rekan kerja, serta brosur dan iklan yang diberikan Jamkrida Sumsel. Sementara itu media sosial belum begitu di optimalkan. Dimensi "evaluasi alternatif'mendapatkan skor rata - rata 3.00, kategori sedang. Hal ini dapat disimpulkan bahwa Asuransi jamkrida saat ini mampu menjadi alternatif pilihan solusi dalam hal jasa penjaminan kredit daerah bagi pelanggan di Sumatera Selatan. Namun sebagai evaluasi, skor pada kategori sedang atau nilai 3.00, belum cukup untuk menjadikan Jamkrida sebagai pemimpin pasar di wilayah Sumatera Selatan. Untuk itu tetap harus di tingkatkan kualitasnya agar tetap dapat bersaing di masa yang akan datang serta menjaga jarak dengan kompetitor terdekat maupun yang baru akan muncul dalam persaingan.

Dimensi "keputusan pembelian" mendapatkan skor rata-rata 2.85, masuk pada kategori sedang, dapat disimpulkan dimensi keputusan pembelian belum optimal sehingga dibutuhkan usaha yang lebih representatif untuk mendorong persepsi konsumen ke arah yang lebih 
baik khususnya dari sisi harga yang lebih kompetitif dan kemampuan petugas dalam melakukan selling \& Follow up Client.

Dimensi pelayanan pasca pembelian, dengan skor 2,96, masuk pada kategori sedang, dapat disimpulkan bahwa pelayanan pasca pembelian juga belum optimal.

\section{Analisis Regresi Linear Berganda Hasil Analisis Persamaan Model Regresi}

Tabel Coefficient

\begin{tabular}{|c|c|c|c|c|}
\hline \multicolumn{5}{|c|}{ Coefficients $^{2}$} \\
\hline & \multirow{2}{*}{ Model } & \multicolumn{2}{|c|}{ Unstandardized Coefficients } & \multirow{2}{*}{$\begin{array}{c}\text { Standardized } \\
\text { Coefficients } \\
\text { Beta }\end{array}$} \\
\hline & & B & Std. Error & \\
\hline \multirow{3}{*}{1} & (Constant) & -0.16 & 0.187 & \\
\hline & Ba.Promosi & 0.576 & 0.059 & 0.601 \\
\hline & K.Pelayanan & 0.443 & 0.067 & 0.408 \\
\hline
\end{tabular}

Berdasarkan hasil olah data tersebut dirumuskan persamaan regresi sebagai berikut:

$$
Y=-0.160+0.576 X_{1}+0.443 X_{2}+e
$$

Jadi berdasarkan hasil persamaan regresi linear berganda diatas dapat disimpulkan bahwa, koefisien yang nilainya paling besar adalah variabel bauran promosi $\left(\mathrm{X}_{1}\right)$. Artinya diantara kedua variabel tersebut, variabel bauran promosi $\left(\mathrm{X}_{1}\right)$ adalah variabel yang pengaruhnya lebih dominan terhadap variabel keputusan pengguna jasa jamkrida Sumsel.

Uji Koefisien Korelasi (r) dan Uji Koefisien Determinasi $\left(r^{2}\right)$

Tabel Uji Koefisien Determinasi

\begin{tabular}{|c|c|c|c|c|}
\hline \multicolumn{5}{|c|}{ Model Summary } \\
\hline Model & R & R Square & Adjusted R Square & $\begin{array}{l}\text { Std. Error of the } \\
\text { Estimate }\end{array}$ \\
\hline 1 & $.889^{\mathrm{a}}$ & 0.79 & 0.784 & 0.26456 \\
\hline \multicolumn{5}{|c|}{ a. Predictors: (Constant), K.Pelayanan, Ba.Promosi } \\
\hline \multicolumn{5}{|c|}{ b. Dependent Variable: Keputusan } \\
\hline
\end{tabular}

Berdasarkan hasil pengolahan data di atas, Koefisien korelasi (r) berada pada angka 0.889 atau berkisar pada interval
$(0.80-1.00)$ yang artinya hubungan antar variabel independen (X) dan variabel dependen (Y) berada pada kategori interval sangat kuat. Selanjutnya Koefisien determinasi $\left(\mathrm{r}^{2}\right)$, Nilai koefisien determinasi $\left(\mathrm{r}^{2}\right)$ adalah 0.790 atau $79.0 . \%$. Hal ini menunjukkan bahwa persentase pengaruh variabel bebas (Bauran Promosi \& Kualitas Pelayanan) terhadap variabel terikat (Keputusan) mampu menjelaskan $79.0 \%$ variabel terikat, sedangkan sisanya sebesar $21.0 \%$ dipengaruhi atau dijelaskan oleh variabel lain yang tidak dimasukkan dalam model penelitian ini.

\section{Pengujian Hipotesis \\ Uji Kesesuaian Model Regresi (Model Fit - F Signifikan)}

Berikut ini adalah hasil uji signifikansi (Uji-F) yang digunakan pada penelitian ini sebagai berikut :

\section{Tabel Hasil Uji F}

\begin{tabular}{|c|c|c|c|c|c|c|}
\hline \multicolumn{7}{|c|}{ ANOVA $^{\mathrm{a}}$} \\
\hline & Model & Sum of Squares & df & Mean Square & $\mathrm{F}$ & Sig. \\
\hline \multirow{3}{*}{1} & Regression & 20.225 & 2 & 10.113 & 144.488 & $.000^{b}$ \\
\hline & Residual & 5.389 & 77 & 0.07 & & \\
\hline & Total & 25.615 & 79 & & & \\
\hline \multicolumn{7}{|c|}{ a. Dependent Variable: Keputusan } \\
\hline \multicolumn{7}{|c|}{ b. Predictors: (Constant), K.Pelayanan, Ba.Promosi } \\
\hline
\end{tabular}

Berdasarkan hasil output data SPSS uji-F (Anova ${ }^{a}$ ) didapat bahwa nilai $\mathrm{F}$ hitung yang diperoleh adalah $144.488>\mathrm{F}$ tabel sebesar 2.370 dan tingkat kemaknaan secara serentak sig $\mathrm{F}$ adalah 0,000 . Hal ini menunjukkan bahwa secara bersama-sama (simultan) variabel bebas yang ada dalam penelitian yaitu Bauran Promosi $\left(\mathrm{X}_{1}\right)$ dan Kualitas Pelayanan $\left(\mathrm{X}_{2}\right)$ memiliki pengaruh yang signifikan terhadap variabel terikat Keputusan Pengguna Jasa Jamkrida Sumsel (Y).

\section{Uji Pengaruh Kausalitas (Model $t$ Signifikan)}

Uji $\mathrm{t}$ pada dasarnya menunjukkan seberapa jauh pengaruh suatu variabel 
penjelas (variabel $\mathrm{X}_{1}, \mathrm{X}_{2}$ ) secara parsial (individual) dalam menerangkan variasi variabel terikat (Sanusi, 2011:145).

Berikut ini adalah hasil uji signifikansi (Uji-t) yang digunakan untuk menjawab hipotesis penelitian sebagai berikut :

Tabel Hasil Uji t

\begin{tabular}{|c|c|}
\hline \multicolumn{2}{|c|}{ Coefficients $^{\mathbf{a}}$} \\
\hline $\mathbf{t}$ & Sig. \\
\hline-0.857 & 0.394 \\
9.721 & 0 \\
\hline 6.595 & 0 \\
\hline a. Dependent Variable: Keputusan
\end{tabular}

Hipotesis 1 : Berdasarkan hasil Uji Signifikansi variabel Bauran Promosi $\left(\mathrm{X}_{1}\right)$ di dapatkan nilai signifikan pada $\alpha=0.1$ karena nilai t-hitung > t-tabel (9.721 > 1.292) atau nilai (Sig.) $0.000<0.1$. Artinya pengaruh Bauran Promosi Jamkrida Sumsel $\left(\mathrm{X}_{1}\right)$ terhadap Keputusan Pengguna Jasa $(\mathrm{Y})$ adalah signifikan. Ini juga membuktikan bahwa hipotesis pertama yang menyatakan bahwa diduga terdapat pengaruh antara variabel Bauran Promosi $\left(\mathrm{X}_{1}\right)$ terhadap Keputusan Pengguna Jasa Jamkrida Sumsel (Y) dapat diterima.

Hipotesis 2 : Berdasarkan hasil Uji Signifikansi Variabel Kualitas Pelayanan $\left(\mathrm{X}_{2}\right)$ di dapatkan nilai signifikan pada $\alpha=$ 0.1 karena nilai t-hitung $>$ t-tabel $(6.595>$ 1.292) atau nilai (Sig.) $0.000<0.1$. Artinya pengaruh Kualitas Pelayanan $\left(\mathrm{X}_{2}\right)$ terhadap Keputusan Pengguna Jasa (Y) adalah signifikan. Ini juga membuktikan bahwa hipotesis kedua yang menyatakan bahwa diduga terdapat Kualitas Pelayanan $\left(\mathrm{X}_{2}\right)$ terhadap Keputusan Pengguna Jasa Jamkrida Sumsel (Y) dapat diterima.

\section{Pembahasan}

Berdasarkan hasil pengolahan data statistik, Koefisien korelasi (r) berada pada angka 0.889 atau berkisar pada interval $(0.80-1.00)$ yang artinya hubungan antar variabel independen (X) dan variabel dependen (Y) berada pada kategori interval sangat kuat.
Selanjutnya Koefisien determinasi $\left(\mathrm{r}^{2}\right)$, Nilai koefisien determinasi $\left(\mathrm{r}^{2}\right)$ adalah 0.790 atau 79.0.\%. Hal ini menunjukkan bahwa persentase pengaruh variabel bebas (Bauran Promosi \& Kualitas Pelayanan) terhadap variabel terikat (Keputusan) mampu menjelaskan $79.0 \%$ variabel terikat, sedangkan sisanya sebesar $21.0 \%$ dipengaruhi atau dijelaskan oleh variabel lain yang tidak dimasukkan dalam model penelitian ini.

Dari hasil uji-F (Anova) didapat bahwa nilai $F$ hitung yang diperoleh adalah 144.488 lebih besar dari $\mathrm{F}$ tabel sebesar 2.370 dan tingkat kemaknaan secara serentak sig F adalah 0,000. Hal ini menunjukkan bahwa secara bersamasama (simultan) variabel bebas yang ada dalam penelitian yaitu Bauran Promosi $\left(\mathrm{X}_{1}\right)$ dan Kualitas Pelayanan $\left(\mathrm{X}_{2}\right)$ memiliki pengaruh yang signifikan terhadap variabel terikat Keputusan Pengguna Jasa Jamkrida Sumsel (Y). Hasil uji $\mathrm{F}$ yang telah dilakukan ini juga membuktikan bahwa model penelitian yang diajukan pada penelitian ini dinyatakan telah sesuai (Fit) karena telah memenuhi seluruh asumsi yang berlaku.

\section{Tabel Ringkasan Hasil Penelitian}

\begin{tabular}{|c|c|c|}
\hline No & Rangkuman & Hasil Pengujian \\
\hline 1 & Hipotegis ! & Diterim \\
\hline 2 & Hipoteàs 2 & Diterima \\
\hline 3 & Hipotesis 3 & Diterima \\
\hline 4 & Hasil Uji Kesesuaian Modal (F- Signifikan) & ModelFit \\
\hline 5 & Koefisien korelasi (s) & 0.889 (Kuat) \\
\hline 6 & Koefisien determinas $\left(R^{*}\right)$ & $0.790 / 79.0 \%$ \\
\hline 7 & Modal Persamasn Regres & $Y=-0.160+0.576 X 1+0.443 X 2$ \\
\hline & & te \\
\hline 8 & Bavran Pemascran (Score) & 3.16/3/(Kategori Sadang) \\
\hline 9 & Kualias Pelayanan & $2.93 / 3 /$ (Kategori Sadarg) \\
\hline 10 & Keputusan Pelanggen & 3.05/3/(Kategori Sedang) \\
\hline
\end{tabular}

\section{SIMPULAN}

\section{Kesimpulan}

Berdasarkan analisis dan pembahasan maka dapat ditarik kesimpulan sebagai berikut :

1. Variabel Bauran Promosi ( $\left.\mathrm{X}_{1}\right)$ berpengaruh secara positif dan 
signifikan terhadap Keputusan

Pengguna Jasa Jamkrida Sumatera

Selatan.

2. Variabel Kualitas Pelayanan $\left(X_{2}\right)$ berpengaruh secara positif dan signifikan terhadap Keputusan Pengguna Jasa Jamkrida Sumatera Selatan.

3. Variabel Bauran Promosi $\left(\mathrm{X}_{1}\right)$ merupakan variabel independent yang pengaruhnya lebih dominan terhadap Keputusan Pengguna Jasa Jamkrida Sumatera Selatan di bandingkan variabel kualitas pelayanan.

\section{Saran}

Berdasarkan hasil analisis dan pembahasan dalam penelitian ini, dapat dikemukakan saran sebagai berikut :

1. Keterbatasan Hasil Penelitian:

Penelitian ini di lakukan hanya pada satu perusahaan yang bergerak di bidang jasa penjaminan kredit daerah. Zona penelitian juga hanya terbatas pada wilayah Provinsi Sumatera Selatan. Diharapkan bagi penelitian berikutnya dapat menambah jumlah perusahaan sejenis sehingga hasil penelitian dapat digeneralisasi secara luas pada industri sejenis yang ada di Sumatera Selatan ataupun wilayah lainnya.

\section{Manfaat Teoritis :}

Bagi penelitian selanjut dapat menambahkan variabel - variabel lain yang belum diprediksi pada penelitian ini seperti: Citra Merek, Lokasi, Produk, Dan Kesesuaian Harga.

3. Manfaat Praktis :

Implikasi hasil penelitian bagi pihak manajemen Jamkrida Sumsel :

a) Pada penelitian ini Bauran promosi yang dilakukan di nilai belum optimal. Di antaranya kegiatan publisitas yaitu pada kategori Berita TV \& Radio, serta promosi lewat kegiatan social dan sponsorship masih sangat jarang di lakukan. Untuk itu manajemen dapat memprioritaskan program tersebut di masa yang akan datang. tentunya dengan cara yang kreatif dan efisien.

b) Berdasarkan hasil rekapitulasi pernyataan responden pada variabel kualitas pelayanan dapat disimpulkan bahwa kualitas pelayanan yang diberikan Jamkrida Sumsel juga belum begitu optimal. Khususnya pada kriteria empati, bukti fisik, dan daya tanggap. Untuk itu manajemen dapat mengambil suatu kebijakan dalam rangka memperbaiki kualitas pelayanan dari sisi tangibles (bukti fisik), serta melalui pengembangan SDM dalam hal ini tenaga pemasaran agar dapat mengembangkan kemampuan interpersonal serta kemampuan responsiveness dalam pelayanan.

Untuk keputusan pengguna jasa Jamkrida faktor - faktor pemicu keputusan dinilai belum begitu kuat saat ini. Hal ini di karenakan beberapa dimensi yang belum optimal dalam penerapannya. Salah satu di antaranya mengenai dimensi keputusan pembelian pada kategori harga. Harga yang di tawarkan dinilai belum kompetitif menurut responden. Untuk itu manajemen dapat meninjau ulang mengenai kesesuaian harga tersebut agar dapat mendorong keputusan pelanggan di masa yang akan datang.

\section{DAFTAR PUSTAKA}

Ferdinand, A. (2006). Metode Penelitian Manajemen Pedoman Penelitian untuk Penulisan Skripsi Tesis dan disertai Ilmu Manajemen. Semarang: Universitas Diponegoro.

Ghozali, I. (2016). Aplikasi Analisis Multivariete Dengan Program IBM SPSS 23 (Edisi 8). Cetakan ke VIII. In Penelitian. https://doi.org/10.1021/ol7029646

H. Lovelock, C., \& Wirtz, J. (2011). 
Services Marketing: People, Technology, Strategy, 7th edition. Pearson.

Imansyah, N., Rahmawati, E., \& Maryono. (2015). Pengaruh Bauran Promosi terhadap Keputusan Nasabah Menabung Simpeda pada Bank Kalsel Unit Gambut. Jurnal Bisnis Dan Pembangunan, 4(1), 4555.

Imelda, S., \& Sangen, M. (2013). Pengaruh Keputusan Bauran Promosi Terhadap Pengambilan Keputusan Pembelian Nomor Perdana Telkom Flexi di Kota Banjarmasin. Jurnal Wawasan Manajemen, 1(2), 259-280.

Imon, W., Tumbel, A., Mandagie, Y., \& Sam. (2018). Analysis of Factor Affecting Success and Failure in Marketing Strategy. Issn 2303-1174, 6(3), 1308-1317.

Kotler, P., \& Armstrong, G. (2018). Kotler \&amp; Armstrong, Principles of Marketing | Pearson. Pearson.

Kotler, P., \& Keller, K. L. (2009). Manajemen pemasaran jilid 1, edisi Ketiga belas, Terjemahan Bob Sabran. Jakarta: Erlangga. https://doi.org/10.1177/0022022111 434597

Nugroho, F. B., MS, Z. A., \& Sunarti. (2013). Pengaruh Kualitas Pelayanan Terhadap Kepuasan Pelanggan (Survei Pada Nasabah Kredit Program Usaha Kecil Menengah/ Mikro PT. Bank Jatim (Persero) Cabang Kraksaan). Jurnal Administrasi Bisnis, 05(02), 1-19.

Presiden RI. (2010). Peraturan Presiden Republik Indonesia Tentang Pengadaan Barang / Jasa Pemerintah Dengan Rahmat Tuhan Yang Maha Esa Presiden Republik Indonesia ,. (1).
Setiawan, D., \& Masdupi, E. (2019). Pengaruh Kualitas Pelayanan, Kualitas Produk Dan Kepuasan Nasabah Terhadap Loyalitas Nasabah Taplus Bni Cabang Solok, Tesis Program Magister Manajemen Universitas Negeri Padang. Jurnal Riset Manajemen Bisnis Dan Publik, 53(9), 1689-1699. https://doi.org/10.1017/CBO978110 7415324.004

Simamora, B. (2003). Memenangkan Pasar dengan Pemasaran Efektif dan Profitabel (p. 285). p. 285.

Sugiyono, P. D. metode penelitian kuantitatif, kualitatif,dan R\&D. , Alfabeta, cv. (2016).

Sumarman, S. (2002). Pengaruh Bauran Promosi Terhadap Keputusan Konsumen - Menabung Britama Di Kantor Cabang Bank Rakyat Indonesia Muara Bungo.

Ferdinand, A. (2006). Metode Penelitian Manajemen Pedoman Penelitian untuk Penulisan Skripsi Tesis dan disertai Ilmu Manajemen. Semarang: Universitas Diponegoro.

Ghozali, I. (2016). Aplikasi Analisis Multivariete Dengan Program IBM SPSS 23 (Edisi 8). Cetakan ke VIII. In Penelitian. https://doi.org/10.1021/ol7029646

H. Lovelock, C., \& Wirtz, J. (2011). Services Marketing: People, Technology, Strategy, 7th edition. Pearson.

Imansyah, N., Rahmawati, E., \& Maryono. (2015). Pengaruh Bauran Promosi terhadap Keputusan Nasabah Menabung Simpeda pada Bank Kalsel Unit Gambut. Jurnal Bisnis Dan Pembangunan, 4(1), 4555.

Imelda, S., \& Sangen, M. (2013). Pengaruh Keputusan Bauran 
Promosi Terhadap Pengambilan Keputusan Pembelian Nomor Perdana Telkom Flexi di Kota Banjarmasin. Jurnal Wawasan Manajemen, 1(2), 259-280.

Imon, W., Tumbel, A., Mandagie, Y., \& Sam. (2018). Analysis of Factor Affecting Success and Failure in Marketing Strategy. Issn 2303-1174, 6(3), 1308-1317.

Kotler, P., \& Armstrong, G. (2018). Kotler \&amp; Armstrong, Principles of Marketing |Pearson. Pearson.

Kotler, P., \& Keller, K. L. (2009). Manajemen pemasaran jilid 1, edisi Ketiga belas, Terjemahan Bob Sabran. Jakarta: Erlangga. https://doi.org/10.1177/0022022111 434597

Nugroho, F. B., MS, Z. A., \& Sunarti. (2013). Pengaruh Kualitas Pelayanan Terhadap Kepuasan Pelanggan (Survei Pada Nasabah Kredit Program Usaha Kecil Menengah/ Mikro PT. Bank Jatim (Persero) Cabang Kraksaan). Jurnal Administrasi Bisnis, 05(02), 1-19.

Presiden RI. (2010). Peraturan Presiden Republik Indonesia Tentang Pengadaan Barang / Jasa Pemerintah Dengan Rahmat Tuhan Yang Maha Esa Presiden Republik Indonesia ,. (1).

Setiawan, D., \& Masdupi, E. (2019). Pengaruh Kualitas Pelayanan, Kualitas Produk Dan Kepuasan Nasabah Terhadap Loyalitas
Nasabah Taplus Bni Cabang Solok, Tesis Program Magister Manajemen Universitas Negeri Padang. Jurnal Riset Manajemen Bisnis Dan Publik, 53(9), 1689-1699. https://doi.org/10.1017/CBO978110 7415324.004

Simamora, B. (2003). Memenangkan Pasar dengan Pemasaran Efektif dan Profitabel (p. 285). p. 285.

Sugiyono, P. D. metode penelitian kuantitatif, kualitatif,dan R\&D. , Alfabeta, cv. (2016).

Sumarman, S. (2002). Pengaruh Bauran Promosi Terhadap Keputusan Konsumen - Menabung Britama Di Kantor Cabang Bank Rakyat Indonesia Muara Bungo.

Sumsel, J. (2020). Perseroan Terbatas Penjaminan Kredit Daerah Sumatera Selatan (p. 01).p. 01.

Surety Bond PT JAMKRIDA SULSEL. (n.d.). Sulsel: 8 January 2020.

Swastha, Basu, I. (2014). Manajemen Pemasaran Modern. Liberty, Yogyakarta. https://doi.org/10.1017/CBO978110 7415324.004

Tjiptono, F. (2014). Pemasaran Jasa Prinsip, Penerapan, dan Penelitiab. Edisi 1.

Tjiptono, F., \& Chandra, G. (2011). Service, Quality \& Satisfaction. Edisi 4. https://doi.org/10.3389/fgene.2015.0 0293 